\title{
COMPARATIVE AETIOLOGICAL STUDIES OF CONGENITAL DIPLEGIA IN SCOTLAND
}

\author{
BY
}

\author{
C. M. DRILLIEN, T. T. S. INGRAM and ELSPETH M. RUSSELL \\ From the Department of Child Life and Health, University of Edinburgh, and the Edinburgh Clinic \\ of the Scottish Council for the Care of Spastics
}

(RECEIVED FOR PUBLICATION NOVEMBER 29, 1961)

The lack of control series has limited the value of many investigations of the aetiology of cerebral palsy (Little, 1862; Patten, 1931; Stewart, 1942; Yannet, 1944). In the present study patients suffering from diplegia are compared in respect of social factors, maternal reproductive history and perinatal history with groups of prematurely and maturely born children derived from approximately the same population.

\section{Case Material and Methods of Study}

The diplegic patients are derived from two series previously described (Ingram and Russell, 1961). The first of these series was obtained as a result of a regional survey of patients suffering from cerebral palsy in the childhood population of Edinburgh, born between 1938 and 1952 (Ingram, 1961). It comprised 79 patients. The second comprised 200 patients suffering from diplegia who were referred to the Scottish Council for the Care of Spastics between 1945 and 1959. They came from all over Scotland, though the majority lived in the south-east part of the country. In most cases both parents were Scottish. Their ages at the time of referral varied from 13 months to 30 years. Since they were referred to a special clinic, some degree of selection must be assumed, but in most of the respects in which they were studied the patients were very similar to the Edinburgh group. The two series were combined, making a total of 279 patients; but 35 patients who were the result of multiple birth, 14 patients who were illegitimate and one about whom there was insufficient information were all excluded from the series. Table 1 gives the birth weight distribution of the remaining 229 legitimate singletons.

It will be observed that the distribution by birth weight is biphasic, as in a number of recently published series of diplegic children (Childs and Evans, 1954; Russell, 1960). Compared to all live births there is an excess of babies weighing $8 \mathrm{lb}$.
(3.6 kg.) or more and an excess of babies weighing $4 \frac{1}{2} \mathrm{lb} .(2 \cdot 0 \mathrm{~kg}$.) or less (Churchill, 1958). There was a relatively small proportion (19 patients or $8.3 \%$ of cases) weighing between $4 \frac{1}{2}\left(2 \cdot 0 \mathrm{~kg}\right.$.) and $5 \frac{1}{2} \mathrm{lb}$. $(2 \cdot 4 \mathrm{~kg}$.). This group probably contains a number of babies, premature by weight, who are more properly considered as small full-term infants, for more than half of them had reported gestation times of more than 37 weeks (Polani, 1958, 1959). Since the total number of patients weighing between $4 \frac{1}{2}$ and $5 \frac{1}{2} \mathrm{lb}$. ( 2.0 and $2.4 \mathrm{~kg}$.) was small and we wished to make a comparison of the major groups of maturely and prematurely born diplegic patients, the 19 diplegic infants weighing between $4 \frac{1}{2}$ and $5 \frac{1}{2} \mathrm{lb}$. $(2.0$ and $2.4 \mathrm{~kg}$.) were excluded from the series. We were left with two groups, 131 maturely born patients weighing more than $5 \frac{1}{2} \mathrm{lb} .(2 \cdot 4 \mathrm{~kg}$.) and 79 relatively small prematurely born patients weighing $4 \frac{1}{2} \mathrm{lb} .(2 \cdot 0 \mathrm{~kg}$.) or less.

The information obtained about these groups was compared with:

(1) Data derived from the Annual Report of the Registrar-General for Scotland (1959) relating to the general population.

(2) The reproductive histories of a sample of 547 Edinburgh mothers comprising all those giving birth to legitimate surviving singletons in the first week of each quarter of 1959 . These data supply information about abortion rates which are not recorded in the Registrar-General's reports.

TABLE 1

SINGLETON DIPLEGIC PATIENTS BY BIRTH WEIGHT FROM TWO SCOTTISH SERIES

\begin{tabular}{|c|c|c|}
\hline Birth Weight & Number & Per cent. \\
\hline $\begin{array}{l}>5 \text { lb. } 8 \text { oz. }(2.4 \mathrm{~kg} .) \\
>4 \text { lb. } 8 \text { oz. }(2 \cdot 0 \mathrm{~kg} .)<5 \mathrm{lb} .8 \mathrm{oz} . \\
(2.4 \mathrm{~kg} .) \\
4 \mathrm{lb} .8 \mathrm{oz} .(2 \cdot 0 \mathrm{~kg} .) \text { or less } \quad \ldots\end{array}$ & $\begin{array}{r}131 \\
19 \\
79\end{array}$ & $\begin{array}{r}57 \cdot 2 \\
8 \cdot 3 \\
34 \cdot 5\end{array}$ \\
\hline Total . . . . & 229 & $100 \cdot 0$ \\
\hline
\end{tabular}


TABLE 2

PERCENTAGE DISTRIBUTION OF 210 DIPLEGIC PATIENTS AND 91 PREMATURE CONTROLS BY SOCIAL CLASS COMPARED WITH ALL LEGITIMATE LIVE BIRTHS IN SCOTLAND, 1959 (Registrar-General for Scotland, 1959)

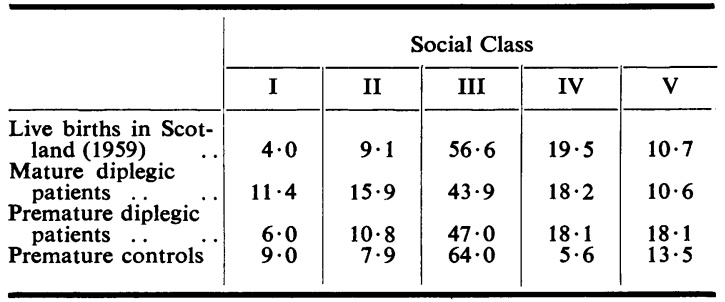

(3) Data obtained about two groups of children born in Edinburgh hospitals during the years 1953 to 1955 and included in a longitudinal study of growth and development now in its eighth year (Drillien, 1958).

The premature control group included 91 children whose birth weight was $4 \frac{1}{2} \mathrm{lb} .(2 \cdot 0 \mathrm{~kg}$.) or less. The reasons for believing that this group does not differ with respect to social class and birth rank from babies of this weight in the general population are given elsewhere (Drillien, 1958).

The mature control group included 111 children whose birth weight was over $5 \frac{1}{2} \mathrm{lb} .(2 \cdot 4 \mathrm{~kg}$.). This group is similar in social class composition to total Edinburgh births, but being a hospital born sample it is somewhat deficient in second and third births and shows slight excess of first births. However, the proportion of first births in the mature control $(52.9 \%)$ was found to be almost identical to that in the mature diplegic group $(52 \cdot 2 \%)$.

\section{Findings}

Social Class Distribution. Table 2 gives the percentage distribution by social class for mature and premature diplegic patients, premature controls and that for all legitimate live births in Scotland (1959). There is a statistically significant excess of mature patients with fathers in social classes I and II compared with those in the general population $\left(\chi^{2}=5 \cdot 260\right)$ at the expense of social class III. In the premature diplegic group there is an excess of patients with fathers in social class $\mathrm{V}$, also at the expense of social class III. This is not due solely to the well-recognized increase in prematurity in the lower social classes, for mothers in social classes IV and $\mathrm{V}$ more often produced children weighing between $4 \frac{1}{2}$ and $5 \frac{1}{2} \mathrm{lb}$. $(2.0$ and $2.4 \mathrm{~kg}$.) at birth than infants of less than $4 \frac{1}{2} \mathrm{lb} .(2.0 \mathrm{~kg}$.) in weight. In the longitudinal study from which the control premature children were taken a distinct difference was noted in the social class distribution of the fathers of those premature babies who weighed more than $4 \frac{1}{2} \mathrm{lb}$. $\left(2.0 \mathrm{~kg}\right.$.) but less than $5 \frac{1}{2} \mathrm{lb}$. $\left(2.4 \mathrm{~kg}\right.$.) and those who weighed $4 \frac{1}{2} \mathrm{lb} .(2.0 \mathrm{~kg}$.) or less. Fathers with premature babies weighing $4 \frac{1}{2} \mathrm{lb} .(2 \cdot 0 \mathrm{~kg}$.) or less were twice as often in social class $I$ and half as often in social class $V$ as were fathers of premature babies weighing more than $4 \frac{1}{2} \mathrm{lb} .(2 \cdot 0 \mathrm{~kg}$. $)$.

When the social class distribution of fathers of premature diplegic patients was compared with fathers of premature controls, a statistically significant excess in social classes IV and V was found in the diplegic group $\left(\chi^{2}=7 \cdot 898\right)$.

\section{The Mother}

Age at Marriage. Fig. 1 shows the distribution by age at marriage of mothers of mature and premature diplegic children, premature control children and women in the general population in Scotland (1958). In the last group, women who married at age 45 years or older have been excluded, as most of these will not have any further children. The mean age at marriage of each group is also given. Mothers of mature diplegic patients married later than women in the general population. This is not due to the observed excess of mothers in social classes I and II. Subdivision by social class showed that average age at marriage was almost identical for all classes. This differs from the age of marriage

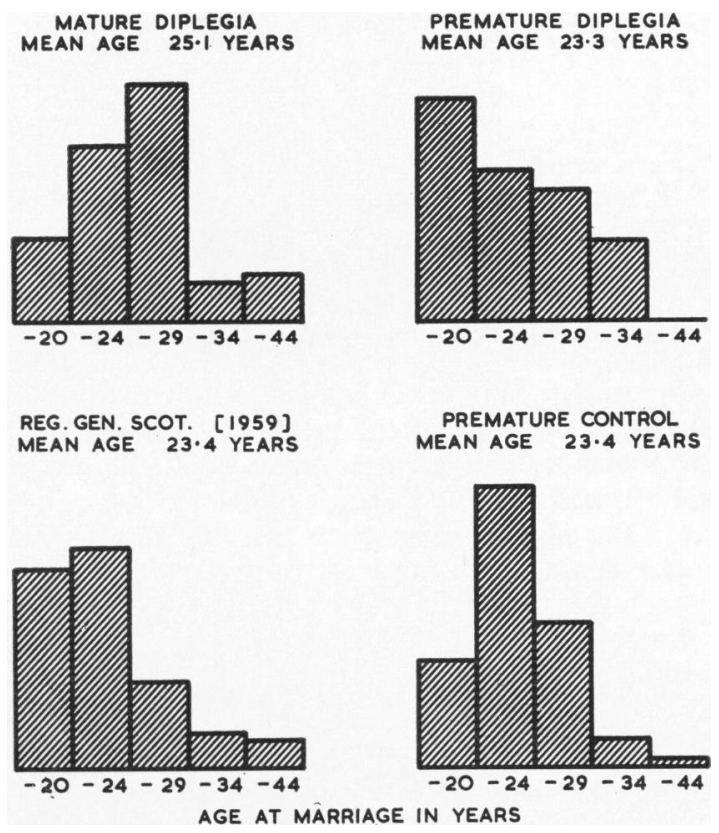

FIG. 1.-Distribution by age at marriage of mothers of mature and premature diplegic children, premature controls and women in general population. 
TABLE 3

RATES OF PREMARITAL CONCEPTIONS FOR FIRST-BORN CHILDREN

\begin{tabular}{ll|c}
\hline & Per cent. \\
\cline { 2 - 3 } & & $17 \cdot 6$ \\
Registrar-General & $\ldots$ & $12 \cdot 1$ \\
Mature diplegic & $\ldots$ & $8 \cdot 7$ \\
Mature control $\ldots$ & $\ldots$ & $33 \cdot 0$ \\
Premature diplegic & $\ldots$ & $16 \cdot 0$ \\
\hline
\end{tabular}

TABLE 4

RATES OF PREMARITAL CONCEPTION IN HANDICAPPED (INCLUDING DIPLEGIC PATIENTS) AND NON-HANDICAPPED PREMATURE FIRST-BORN CHILDREN

\begin{tabular}{l|c|c|c|c}
\hline & \multicolumn{3}{|c}{ Premarital Conception } \\
\cline { 3 - 5 } & & Total & Number & Per cent. \\
\hline Handicapped &. & 36 & 13 & $36 \cdot 1$ \\
Non-handicapped & $\cdots$ & 29 & 2 & 6.9 \\
\hline
\end{tabular}

TABLE 5

AVERAGE AGE OF MOTHER (IN YEARS) AT BIRTH OF AFFECTED OR CONTROL CHILD BY BIRTH RANK (EXCLUDING PREVIOUS ABORTIONS) AND CONCEPTION ORDER (INCLUDING PREVIOUS ABORTIONS)

\begin{tabular}{|c|c|c|c|c|c|}
\hline & & \multicolumn{4}{|c|}{ Birth Rank } \\
\hline & & 1 & & & 3 \\
\hline \multirow[t]{3}{*}{$\begin{array}{l}\text { Registrar-General } \\
\text { Mature diplegics } \\
\text { Premature diplegics } \\
\text { Premature controls }\end{array}$} & $\begin{array}{l}. \\
\therefore \\
\cdots \\
.\end{array}$ & $\begin{array}{l}24 \cdot 4 \\
27 \cdot 9 \\
25 \cdot 3 \\
27 \cdot 8\end{array}$ & & & $\begin{array}{l}29 \cdot 0 \\
33 \cdot 7 \\
29 \cdot 7 \\
31 \cdot 2\end{array}$ \\
\hline & & \multicolumn{4}{|c|}{ Conception Order } \\
\hline & & 1 & 2 & 3 & 4 \\
\hline $\begin{array}{l}\text { Total Edinburgh births } \\
\text { Mature diplegics . . } \\
\text { Premature diplegics } \\
\text { Premature controls }\end{array}$ & $\begin{array}{l}\cdots \\
\cdots \\
\cdots\end{array}$ & $\begin{array}{l}24 \cdot 0 \\
27 \cdot 9 \\
24 \cdot 7 \\
26 \cdot 6\end{array}$ & $\begin{array}{l}27 \cdot 2 \\
31 \cdot 0 \\
28 \cdot 4 \\
28 \cdot 4\end{array}$ & $\begin{array}{l}28 \cdot 8 \\
32 \cdot 9 \\
28 \cdot 4 \\
29 \cdot 3\end{array}$ & $\begin{array}{l}30 \cdot 9 \\
35 \cdot 3 \\
33 \cdot 2 \\
31 \cdot 4\end{array}$ \\
\hline
\end{tabular}

in the general population which progressively decreases from class I to class V. Conversely, mothers of premature diplegic patients tended to marry rather younger than mothers of premature controls or women in the general population. In the premature diplegic group there is also an excess of older marriages ( 30 years and over) which raises the mean age of marriage to that of the general population. These differences in marriage age cannot be attributed to social class. Mothers of premature diplegic patients in social classes I and II were the youngest at marriage, mean age being 22.8 years compared with 25.4 years in the mature diplegic group and $25 \cdot 3$ years in the premature control group.

Premarital Conception. Children mature by weight at birth, i.e. over $5 \frac{1}{2} \mathrm{lb}$. $(2 \cdot 4 \mathrm{~kg}$. $)$, were considered to be premaritally conceived when born within eight months of marriage. In the premature groups allowance has been made for the estimated degree of prematurity. Table 3 gives rates of premarital conception for first-born children by present husband, for premature and mature diplegic and control children, and the comparable figure derived from the Registrar-General's data. No less than $33 \%$ of premature diplegic patients were conceived before marriage compared with $12 \%$ of mature diplegic patients and $17 \cdot 6 \%$ of births in the general population. In the control premature group, nine first-born children have cerebral palsy or other severe handicap. In Table 4 these nine children have been added to the first-born premature diplegic patients and constitute a handicapped group. The incidence of premarital conception in this group is $36.1 \%$ compared with $6.9 \%$ in the nonhandicapped group. In spite of the small numbers, this difference is statistically significant $\left(\chi^{2}=7 \cdot 722\right)$.

The increased incidence of premarital conception in the handicapped group is not due to an excess of mothers of lower social class. In each social class the incidence of premarital conception is higher in the handicapped group than in the non-handicapped. The numbers are too small to allow of subdivision into separate social classes, but taking the incidence of premarital conception in handicapped and nonhandicapped children a statistically significant difference is found when comparing social classes I, II and III together $\left(\chi^{2}=6 \cdot 695\right)$ and also when comparing social classes III, IV and V together $\left(\chi^{2}=5 \cdot 857\right)$.

Age of Mother at Birth of Affected Child. Table 5 gives the average age of mothers at the births of mature and premature diplegic patients and premature controls according to birth rank (including previous stillbirths and neonatal deaths, but excluding previous abortions) and order of conception (including previous abortions). Average maternal age by birth rank for legitimate births in the general population are given for comparison in the upper section of the Table, and average maternal age by conception order for total Edinburgh births in the lower section of the Table. The average age, by parity, of mothers at the births of mature diplegic children is higher than that for mothers in the general population, by three and a half years for first births and by five years for second and third births. At marriage these mothers were about two years older on average. Mothers of premature diplegic children also appear to be rather older by parity as compared with the Registrar-General's figures. However, comparison with total Edinburgh births indicates that if abortions are taken 
into account, the average age by conception rate is about the same as that for Edinburgh mothers. The high rate of loss in previous conceptions by abortion, in mothers of premature diplegic children, will be referred to in a later section.

Spacing of Other Conceptions. Table 6 gives the mean interval in years between the birth of premature and mature diplegic children and preceding births compared with comparable data for all Edinburgh births. In the mature diplegic groups spacing is markedly longer to the birth immediately preceding the affected child and to a lesser degree to the birth before that suggesting that mothers are relatively less fertile at this time than at others. There is no difference in spacing between second and third preceding or earlier births. The number of births subsequent to affected children is not large enough for analysis.

No difference is found in spacing to preceding births in the premature diplegic groups as compared with total Edinburgh births.

Fertility. The fertility of mothers in the diplegic and control groups was studied in a number of ways. First, the average number of children born to mothers by their present husbands during the interval from marriage to the birth of the last child was studied. Table 7 shows that mothers of mature diplegic children have the smallest families. The size of families including a premature diplegic or control child is about the same as that for families in the general population, by duration of marriage. Second, the interval elapsing between marriage and the birth of the first child (whether this was an affected child or not) was examined. Of mothers of mature diplegic patients, $24 \%$ had been married for three years or longer before the birth of their first child, compared with $12 \%$ of parous married women in the general population and $12 \%$ of mothers of premature diplegic children.

Third, the premature and mature diplegic and control groups were compared by certain criteria of subfertility. Although these criteria were somewhat arbitrarily derived they were applied similarly to all mothers. Mothers were considered to be subfertile if they came into the following categories:

(1) Women married for five years or longer with one child, excluding those who were 38 years or older at the birth of the only child.

(2) Women inarried for three years or longer before the first birth, or five years or longer before the first live birth.

(3) A spacing of five years or longer between the affected or control child and the next preceding or succeeding birth.
TABLE 6

MEAN INTERVAL IN YEARS BETWEEN AFFECTED AND CONTROL CHILDREN AND PRECEDING BIRTHS (INCLUD ING ABORTIONS, STILLBIRTHS AND NEONATAL DEATHS)

\begin{tabular}{l|c|c|c|c|c}
\hline & \multicolumn{5}{|c}{$\begin{array}{c}\text { Mean Interval in Years to } \\
\text { Preceding Births }\end{array}$} \\
\cline { 2 - 6 } & First & Second & Third & Fourth & Fifth \\
\hline Edinburgh sample. & $3 \cdot 1$ & $5 \cdot 7$ & $7 \cdot 7$ & $9 \cdot 7$ & $11 \cdot 4$ \\
Mature diplegics & $3 \cdot 8$ & $6 \cdot 8$ & $8 \cdot 9$ & $10 \cdot 3$ & $12 \cdot 1$ \\
Premature diplegics & $3 \cdot 0$ & $6 \cdot 1$ & $8 \cdot 2$ & $9 \cdot 9$ & $11 \cdot 4$ \\
\hline
\end{tabular}

TABLE 7

AVERAGE NUMBER OF BIRTHS (INCLUDING STILLBIRTHS AND INFANT DEATHS, BUT EXCLUDING ABORTIONS) BY DURATION OF MARRIAGE TO PRESENT HUSBAND

\begin{tabular}{|c|c|c|c|c|}
\hline & \multicolumn{4}{|c|}{ Duration of Marriage in Years } \\
\hline & -2 & -4 & -6 & -9 \\
\hline $\begin{array}{l}\text { Registrar-General (1959) } \\
\text { Mature diplegics } \\
\text { Premature diplegics }\end{array}$ & $\begin{array}{l}1 \cdot 30 \\
1 \cdot 13 \\
1 \cdot 31 \\
1 \cdot 54\end{array}$ & $\begin{array}{l}2 \cdot 17 \\
1 \cdot 72 \\
2 \cdot 09 \\
2 \cdot 14\end{array}$ & $\begin{array}{l}2 \cdot 72 \\
2 \cdot 00 \\
2 \cdot 69 \\
2 \cdot 35\end{array}$ & $\begin{array}{l}3 \cdot 33 \\
2 \cdot 13 \\
3 \cdot 0 \\
2 \cdot 90\end{array}$ \\
\hline
\end{tabular}

TABLE 8

RELATIVE INFERTILITY OF MOTHERS OF DIPLEGIC CHILDREN AND CONTROLS (HANDICAPPED AND NORMAL)

\begin{tabular}{|c|c|c|c|c|c|}
\hline & Infertile & Fertile & $\begin{array}{c}\text { Not } \\
\text { Known }\end{array}$ & Total & $\begin{array}{l}\text { Per cent. } \\
\text { Infertile }\end{array}$ \\
\hline $\begin{array}{l}\text { Mature controls } \\
\text { (normal) } \ldots\end{array}$ & 23 & 82 & 6 & 111 & 22 \\
\hline $\begin{array}{l}\text { Mature controls } \\
\text { (handicapped) }\end{array}$ & 3 & 1 & - & 4 & 75 \\
\hline Mature diplegics & 59 & 62 & 10 & 131 & 49 \\
\hline (normal) ... & 22 & 44 & - & 66 & 33 \\
\hline $\begin{array}{l}\text { Premature controls } \\
\text { (handicapped) } \\
\text { Premature diplegics }\end{array}$ & $\begin{array}{l}10 \\
23\end{array}$ & $\begin{array}{l}15 \\
54\end{array}$ & $\overline{2}$ & $\begin{array}{l}25 \\
79\end{array}$ & $\begin{array}{l}60 \\
30\end{array}$ \\
\hline
\end{tabular}

In these categories mothers have not been considered subfertile if contraception has been used to delay or prevent pregnancy, or if the parents have been separated for any reason (such as death, divorce, war service, etc.).

(4) All women having three or more conceptions, one-half or more of which have been lost by abortion, stillbirth or neonatal death.

Table 8 gives the numbers of mothers considered subfertile, who gave birth to premature and mature diplegic children and controls. The control children are further subdivided into those who had a severe handicap and those who were normal. It should be remembered that all control children were born in hospital, and some of their mothers may have been admitted to hospital for reason of infertility. The rate in control groups is likely to be higher than that which would be found in the general population. A highly significant excess of subfertility is 
found in the mature diplegic groups as compared with the normal mature control group $\left(\chi^{2}=17 \cdot 537\right)$. The high rate of $75 \%$ subfertility in abnormal mature controls is based on only four cases and may be due to chance. Comparing mothers of mature and premature diplegic patients, the excess of subfertility in the former is also significant $\left(\chi^{2}=6 \cdot 966\right)$. In spite of small numbers, a significant excess of subfertility is found in mothers of abnormal premature controls as compared with normal premature controls $\left(\chi^{2}=5 \cdot 344\right)$.

Abnormalities in Other Conceptions. The conceptions other than those resulting in the birth of the diplegic or control children were studied. A conception was considered to be abnormal in outcome if it resulted in abortion, stillbirth, infant death (under the age of 1 year) or the birth of a child who survived infancy but showed gross congenital defect. Figures for the different groups are shown in Table 9. A highly significant excess of abnormal other conceptions was found for mothers in both premature diplegic and premature control groups as compared with mothers in Edinburgh in 1959. In Edinburgh in 1959 the total of abnormalities in other conceptions was $15 \cdot 7 \%$ compared with $39 \cdot 4$ and $33.3 \%$ for premature diplegic and control groups. Comparing the premature diplegic group with the premature control group, the excess of abnormal conceptions subsequent to the birth of the diplegic children was on the verge of significance at the 0.5 level $\left(\chi^{2}=3.656\right)$.

Frequent losses, defined as the loss of one-half or more of all conceptions by abortion, stillbirth or neonatal death, in women who had three or more conceptions, were found in $4.2 \%$ of mothers in the 1959 Edinburgh sample. A significant excess was found in mothers of premature diplegic patients $\left(\chi^{2}=11 \cdot 721\right)$ and premature controls $\left(\chi^{2}=4 \cdot 709\right)$.

Pregnancy, Labour and Delivery. Comparisons were made of the prevalence of complications of pregnancy, labour and delivery in mothers of diplegic patients and controls.

The following were considered to be complications of pregnancy: Toxaemia excluding cases classified as mild, essential hypertension, threatened abortion, ante-partum haemorrhage, severe hyperemesis necessitating hospital admission, chronic cardiac and pulmonary disease, severe iron deficiency anaemia, megaloblastic anaemia, rubella and operations under general anaesthetic during pregnancy.

The following were included as abnormalities of labour and delivery: Prolonged labour, precipitate delivery, malpresentation, internal version, prolapse
TABLE 9

ABNORMALITIES IN OTHER CONCEPTIONS OF MOTHERS OF DIPLEGIC AND CONTROL CHILDREN

\begin{tabular}{|c|c|c|c|}
\hline & $\begin{array}{l}\text { Mature } \\
\text { Diplegic }\end{array}$ & $\begin{array}{c}\text { Premature } \\
\text { Diplegic }\end{array}$ & $\begin{array}{c}\text { Premature } \\
\text { Control }\end{array}$ \\
\hline $\begin{array}{l}\text { Total number all other con- } \\
\text { ceptions } \\
\text { Percentage abnormal } \\
\text { Total number all previous con- } \\
\text { ceptions } \\
\text { Percentage abnormal } \\
\text { Total number all subsequent } \\
\text { conceptions } \\
\text { Percentage abnormal } \\
\text { Percentage mothers having fre- } \\
\text { quent losses ... ... }\end{array}$ & $\begin{array}{l}196 \\
19 \cdot 8 \\
124 \\
17 \cdot 7 \\
72 \\
23 \cdot 6 \\
0.0\end{array}$ & $\begin{array}{c}169 \\
39 \cdot 4 \\
121 \\
40 \cdot 9 \\
48 \\
35 \cdot 4 \\
18 \cdot 4\end{array}$ & $\begin{array}{c}159 \\
33 \cdot 3 \\
101 \\
41 \cdot 6 \\
58 \\
19 \cdot 0 \\
11 \cdot 6\end{array}$ \\
\hline
\end{tabular}

TABLE 10

PERCENTAGE OF DIPLEGIC PATIENTS AND HOSPITAL BORN CONTROLS WITH COMPLICATIONS OF PREGNANCY, LABOUR AND DELIVERY

\begin{tabular}{|c|c|c|c|c|}
\hline & $\begin{array}{c}\text { Mature } \\
\text { Controls }\end{array}$ & $\begin{array}{c}\text { Mature } \\
\text { Diplegics }\end{array}$ & $\begin{array}{c}\text { Premature } \\
\text { Controls }\end{array}$ & $\begin{array}{l}\text { Premature } \\
\text { Diplegics }\end{array}$ \\
\hline $\begin{array}{l}\text { Number of cases } \\
\text { Normal pregnancy, } \\
\text { labour and delivery } \\
\text { Abnormal pregnancy } \\
\text { only } \\
\text { Abnormal labour or } \\
\text { delivery only } \\
\text { Abnormal pregnancy } \\
\text { and labour or de- } \\
\text { livery ... }\end{array}$ & $\begin{array}{l}111 \\
62 \cdot 2 \\
12 \cdot 6 \\
17 \cdot 1\end{array}$ & $\begin{array}{l}18 \cdot 0 \\
33 \cdot 8\end{array}$ & $\begin{array}{l}91 \\
31 \cdot 4 \\
35 \cdot 9 \\
12 \cdot 4\end{array}$ & $\begin{array}{l}18 \cdot 8 \\
20 \cdot 0\end{array}$ \\
\hline $\begin{array}{l}\text { Total with abnormal } \\
\text { pregnancy } \\
\text { Total with abnormal } \\
\text { labour and delivery }\end{array}$ & $20 \cdot 7$ & $31 \cdot 7$ & $33 \cdot 0$ & $50 \cdot 0$ \\
\hline
\end{tabular}

of cord, cord wound tightly round the infant's neck, delivery by high or mid forceps or caesarean section.

Table 10 gives percentages of diplegic and control cases with these complications of pregnancy, labour and delivery.

It was found that there was an excess of complications of pregnancy in the mature diplegic group as compared to the mature control group. This was on the verge of statistical significance $\left(\chi^{2}=3 \cdot 761\right)$ in spite of the fact that the control group comprised a hospital series and might be expected to show a relatively high prevalence of abnormal pregnancies compared to that found in all births in the general population.

There was a significant excess of abnormalities of labour and delivery in mature diplegic patients compared to the mature controls $\left(\chi^{2}=13 \cdot 030\right)$. This excess was not apparently due to the higher age of the mothers in the diplegic group, for the prevalence of abnormalities did not increase with age in the mothers of diplegic patients, though it did in mature controls (Table 11).

The premature diplegic and premature control 
TABLE 11

A COMPARISON OF MOTHERS OF 72 MATURE FIRST-BORN DIPLEGIC PATIENTS AND 58 HOSPITAL FIRST-BORN CONTROLS BY AGE AND COMPLICATION OF PREGNANCY, LABOUR AND DELIVERY

\begin{tabular}{|c|c|c|c|c|c|c|}
\hline \multirow{3}{*}{$\begin{array}{l}\text { Maternal age in years... } \\
\% \% \text { abnormal pregnancy } \\
\% \text { abnormal labour or } \\
\text { delivery } \\
\text {.. }\end{array}$} & \multicolumn{3}{|c|}{ Mature Controls } & \multicolumn{3}{|c|}{ Mature Diplegics } \\
\hline & $\begin{array}{c}-24 \\
19\end{array}$ & $\begin{array}{c}25-29 \\
21\end{array}$ & $\begin{array}{c}30+ \\
42\end{array}$ & $\begin{array}{c}-24 \\
36\end{array}$ & $\begin{array}{c}25-29 \\
25\end{array}$ & $\begin{array}{c}30+ \\
27\end{array}$ \\
\hline & 25 & 43 & 33 & 59 & 54 & 58 \\
\hline
\end{tabular}

TABLE 12

COMPLICATIONS OF NEONATAL PERIOD BY ABNOR MALITIES OF PREGNANCY, LABOUR AND DELIVERY IN MATURE AND PREMATURE DIPLEGIC PATIENTS AND HOSPITAL BORN CONTROLS

\begin{tabular}{|c|c|c|c|c|}
\hline & \multicolumn{4}{|c|}{ Per Cent. With Neonatal Complications } \\
\hline & \multicolumn{2}{|c|}{ Mature } & \multicolumn{2}{|c|}{ Premature } \\
\hline & Controls & Diplegics & Controls & Diplegics \\
\hline $\begin{array}{c}\text { Normal pregnancy } \\
\text { and delivery }\end{array}$ & $1 \cdot 5$ & $34 \cdot 7$ & $10 \cdot 5$ & $52 \cdot 0$ \\
\hline $\begin{array}{c}\text { Abnormal pregnancy } \\
\text { only }\end{array}$ & $0 \cdot 0$ & $56 \cdot 5$ & $35 \cdot 1$ & $76 \cdot 5$ \\
\hline $\begin{array}{l}\text { Abnormal pregnancy } \\
\pm \text { abnormal deli- } \\
\text { very }\end{array}$ & $4 \cdot 0$ & $67 \cdot 5$ & $35 \cdot 2$ & $82 \cdot 1$ \\
\hline $\begin{array}{l}\text { Abnormal labour or } \\
\text { delivery only } \\
\text { Abnormal labour or }\end{array}$ & $23 \cdot 5$ & $73 \cdot 3$ & $27 \cdot 5$ & $82 \cdot 4$ \\
\hline $\begin{array}{l}\text { delivery } \pm \text { abnor- } \\
\text { mal pregnancy } \\
\text { Abnormal pregnancy }\end{array}$ & $17 \cdot 9$ & $75 \cdot 8$ & $35 \cdot 7$ & $84 \cdot 6$ \\
\hline very $\quad . . \quad .$. & $29 \cdot 1$ & $82 \cdot 4$ & $35 \cdot 2$ & $86 \cdot 3$ \\
\hline
\end{tabular}

groups showed comparable figures for the prevalence of disorders of pregnancy, but there was a significant excess of disorders of labour and delivery in the diplegic group $\left(\chi^{2}=5 \cdot 289\right)$.

The Postnatal Course. The neonatal period was considered abnormal when the baby was reported to be shocked, limp or blue at birth, a poor feeder or to have prolonged jaundice. Those who suffered subsequently from cyanotic attacks, twitching or convulsions were also considered abnormal.

It will be seen from Table 12 that there was a marked excess of complications of the neonatal period in the mature diplegic patients as compared to mature controls. The presence of abnormalities of pregnancy made little difference to the incidence of neonatal disorders in the controls. The incidence rose to a maximum of $23.5 \%$ in cases where there was some complication of labour or delivery. In the mature diplegic patients neonatal abnormalities were increased greatly if either pregnancy, labour or delivery had been complicated. Disorders of labour and delivery appeared to be more important in increasing the likelihood of abnormalities of the neonatal period than were abnormalities of pregnancy.

A higher proportion of premature diplegic patients had complications in the neonatal period than had the premature controls. In both premature and mature diplegic groups it was found that neonatal complications were more frequent after abnormal pregnancy, labour and delivery.

\section{Summary}

A composite series of 229 diplegic patients, all of whom were the result of legitimate singleton births, is compared in respect of social factors, maternal reproductive history and perinatal history with groups of prematurely and maturely born children derived from approximately the same Scottish population. The diplegic patients were divided into two groups, the first comprising children weighing more than $5 \frac{1}{2} \mathrm{lb} .(2 \cdot 4 \mathrm{~kg}$.) at birth, the second weighing $4 \frac{1}{2} \mathrm{lb}$. $(2 \cdot 0 \mathrm{~kg}$.) or less.

Whereas the fathers of mature diplegic patients were more often in social classes I and II and less often in social class III than fathers of all live births in the Scottish population, premature diplegic patients more often had fathers in social classes IV and V and less often fathers in social class III than all live births in the general population.

Mothers of mature diplegic patients married later than women in the general population, whereas mothers of premature diplegic patients married earlier. One-third of all first-born premature diplegic patients were conceived before marriage compared to $12 \cdot 1 \%$ of mature diplegic patients and $17 \cdot 6 \%$ of all live births in Scotland. Whereas the average age of mothers by parity of mature diplegic patients was found to be significantly higher than mothers in the general population, the average age of mothers of premature diplegic patients was little different. Mothers of mature diplegic patients were relatively infertile immediately before the birth of the diplegic patient compared to other times. They were subfertile compared to mothers of all Edinburgh births in 1959 and mothers of premature diplegic patients.

Rather arbitrary criteria of subfertility were devised, and it was found that there was a significant excess of subfertility amongst the mothers of mature diplegic patients compared to the mothers of normal mature controls and of premature diplegic patients. Other conceptions were more often abnormal in the premature diplegic group than in the mature diplegic group or amongst all live births in the Edinburgh population 1959.

There was an excess of complications of pregnancy 
in the mature diplegic group as compared to the mature control group and a greater excess of abnormalities of labour and delivery in mature diplegic patients compared to mature controls. Premature diplegic and premature control groups showed comparable figures for the prevalence of disorders of pregnancy, but there was a significant excess of disorders of labour and delivery in the diplegic group. There was a marked excess of complications of the neonatal period in the mature diplegic patients compared to mature controls, and this difference was accentuated when there had been previous abnormalities of labour or delivery. A higher proportion of premature diplegic patients had complications in the neonatal period than premature controls, and in both groups the neonatal period was more often abnormal if there had been disorders of labour or delivery.

It is suggested that the differences in clinical findings between premature and mature patients recently reported are accompanied by differences in aetiological findings. Whilst perinatal injury may be the aetiological factor of major importance in some patients suffering from diplegia, in others multiple contributory aetiological factors are operating (Freud, 1893, 1897). They may cause the child to be abnormal before birth and predispose him to injury at the time of birth. Their nature and mode of operation require further study, but they differ in maturely and prematurely born patients.

Part of the work reported here was carried out by Dr. C. M. Drillien during a tenure of a Fellowship from the Mental Health Research Trust Fund, by Dr. T. T. S. Ingram (1952-53) during the tenure of a George Guthrie Research Fellowship, and by Dr. E. M. Russell whilst she was a Graduate Research Fellow in the University of Edinburgh. We are very grateful to the many physicians and surgeons in Edinburgh who allowed us access to their patients, and in particular to Dr. James Naughton and Mr. G. A. Pollock of the Edinburgh Clinic, Scottish Council for the Care of Spastics, for their helpful co-operation, and to Miss I. V. Beattie, Superintendent of Health Visitors, Public Health Department, Corporation of Edinburgh, who arranged for the collection of certain control data. Part of the expenses of the investigations was defrayed by a grant from the Scottish Council for the Care of Spastics and from the Hospital Endowments Research Trust.

We are deeply grateful to Professor R. W. B. Ellis for his stimulating interest in the various research projects which were undertaken and for his advice on the preparation of this paper.

\section{REFERENCES}

Childs, B. and Evans, P. R. (1954). Birth weights of children with cerebral palsy. Lancet, 1,642 .

Churchill, J. (1958). The relationship of Little's disease to premature birth. Amer. J. Dis. Child., 96, 32.

Drillien, C. M. (1958). A longitudinal study of the growth and development of prematurely and maturely born children, Part I. Introduction. Arch. Dis. Childh., 33, 417.

Freud, S. (1893). Zur Kenntniss der cerebralen Diplegien des Kindesalters. Deuticke, Leipzig.

- (1897). Die infantile Cerebrallähmung. In Specielle Pathologie und Therapie, ed. H. Nothnagel, Band 9, teil 2, Abt. 2. Hölder, Vienna.

Ingram, T. T. S. (1961). Studies of Cerebral Palsy in the Childhood Population of Edinburgh. M.D. Thesis.

- and Russell, E. M. (1961). The reproductive histories of mothers of patients suffering from congenital diplegia. Arch. Dis. Childh., 36, 34

Little, W. J.. (1862). On the influence of abnormal parturition, difficult labours, premature birth, and asphyxia neonatorum on the mental and physical condition of the child, especially in relation to deformities. Trans. obstet. Soc. Lond., 3, 293.

Patten, C. A. (1931). Cerebral birth conditions with special reference to cerebral diplegia; preliminary report of clinical study. Arch. Neurol. Psychiat. (Ćhicago), 25, 453.

Polani, P. E. (1958). Prematurity and 'cerebral palsy'. Brit. med.J., $2,1497$.

- (1959). Effects of abnormal brain development on function. Cerebral Palsy Bull., 1., No 7, p. 27.

Registrar-General for Scotland (1959). Annual Reports. H.M.S.O., London.

Russell, E. M. (1960). Correlation between birth weight and clinical findings in diplegia. Arch. Dis. Childh., 35, 548.

Stewart, R. M. (1942). Observations on the pathology of cerebral diplegia. Proc. roy. Soc. Med., 36, 25.

Yannet, H. (1944). The etiology of congenital cerebral palsy; statisticil and clinical study. J. Pediat., 24, 38. 